$S 441$

N' 



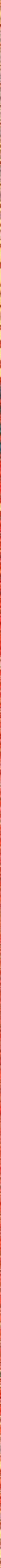








$$
3+2
$$




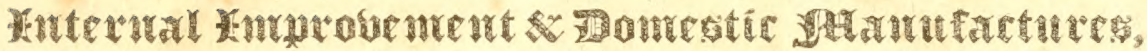

\author{
SHEWING THEIR INSEPERABLE CONNECTION WFTH
}

\section{THE BUSINESS AND INTERESTS OF AGRZUUTURE,}

In the establishment of a home-market for bread-stuffs and meats, wool, cotton, flax, hemp, \&ce as well as the supplies that they will furnish in aid of the foreign commerce of the United States.

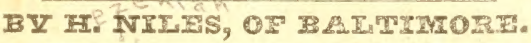 \\ First published in Niles' Register, of March 24, 1827.

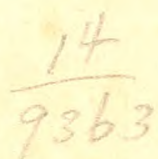 \\ WITH ADDITIONล.
}

After considerable reflection on the subject and careful references to some of the important statistical facts that bear upon it, we have reached the conclusion-that, at no previous time, during the period of our national existence, has the state of our agriculture more imperiously demanded the serious reflection and care of a wise and paternal government, than at the present moment. Though there is, perhaps, less of actual suffering in the United States than in any other country under hearen, a great degree of peeuniary distress and private embarrassment: prevails, and "the prospect before us" is, unless the profound attention of our statesmen shall be excited and exerted to relieve the people, that we cannot advance to those high destinies to which our republic seems called, so certainly and rapidly as we ought. We totally disavow any desire to build up a forced or artificial system, for the benefit of any class of individuals, even for the agricultural, though they make up about three-fourths of our whole population-but hold it to be expedient and proper, at all times, and in behalf even of an individual citizen, to profit by all the advantages which GoD and nature have given, to promote "the general welfare," by securing happiness and prosperity to all, and each, through wholesome employment and reasonable compensation for labor. Foreign commerce, as to many of our late most valuable commodities, fails to produce its former effects, and men have been compelled to turn their attention to new articles; and the mighty changes which have taken place in the condition of our country, in various and important respects, should inspire us with deep and solemn considerations as to the future; and indignantly forbid a yielding to temporary or political-party purposes, whatever may impede the march of prosperity or cause abandonments of immutable principles of right. It is the gift of Providence, that these United States should be free, independent and happy-and it depends upon ourselves whether we shall retain or cast away the blessings bestowed. The policy of this republic, whether it regards agriculture, manufactures or commerce, interior or exterior, must not be subjected to the caprices of transient parties, or made a matter for political bargaining -as has been partially the case heretofore, and, as it appears probable, may be attempted again.

These general remarks naturally occurred when we sat down to make some observations on the past, present and probable state of our agriculturalists-in which we hope to adduce some facts and opinions that will lead many to a serious consideration as to that policy which ought to be steadily pursued. We have no manner of reference to local circumstances or peculiar things, except as they shall appear to affect the well-being of the community at large-and, let factions and parties draw their political or geographical lines as they may, we never yethave believed that there is any material dirersity of interest among the widely scattered people of the United States; and that, in matters of business, the same amicable compromises do, or may, exist, which have been established in our political constitution, under which we have had "peace, liber-s ty and safety," however much we have been agifuted by political feelings-and the jarrings between ins and outs, with the intrigues of those who, in the language of De Witt Clinton, have seemed as if they would "rather reign in $\mathrm{h}-\mathrm{l}$ than serve in heaven."

The chief products of our agriculture are vegetable and animal food and wool, tobacco and. cotton, with considerable quantities of sugar, flax and hemp, \&c. but we shall principally confine our remarks to articles of the first class.

Vegetable and animal food (except rice), are the main agricultural products, for export, from the states of Maine, New Hampshire, Massachusetts, Rhode Island, Connecticut, Vermont, New York, New Jersey, Pennsy\}vania, Delaware, Kentucky, Ohio, Indiana, Illinois-and partly so 
of Maryland, Virginia, 'Tennessee and Missouri. We shall take the three first and the three jas? years inserted in the valuable table given in the 28th vol, of this REGISTER, page 329, to see what progress we have made as to the export of vegetable and animal food:

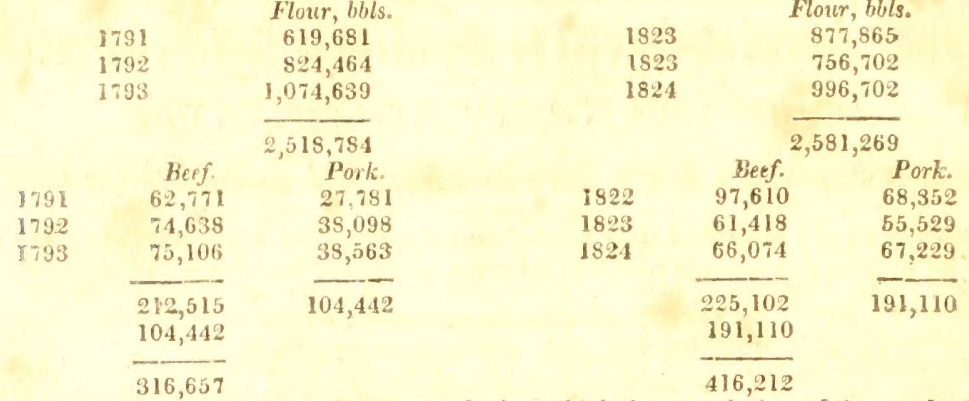

Shewing an increase in thirty-five years, during which the population of the producing states has been almost trebled, of only 62,455 bbls. of flour and 99,255 barrels of beef and pork in three years, or a yearly increased export of 21,000 bbls. of flour and 33,000 barrels of beef and pork. And, in the years 1791,1792 and 1793 we exported 373,352 tierces of rice, and only 301,653 in the years 1822,1823 and 1824 .

It is the quantily that establishes the capacity to produce, or the amount of the foreign demand; but if the money-value of these articles is regarded, it is probable that those exported in the three first years was, nearly, twice as large as that of those exported in the three last. Such value was mot given in the ofticial papers until the year 1503, and, referring again to the table, we have the following items:

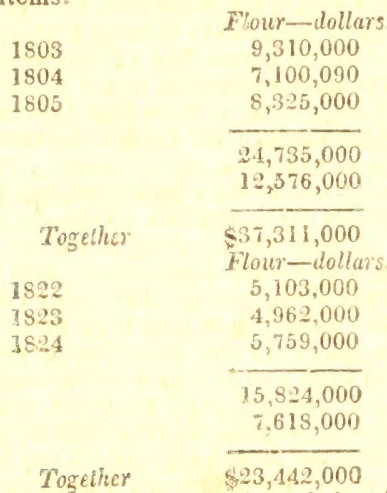

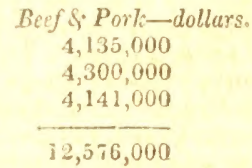

Beef \& Pork-dollars. $2,529,000$ $2,461,000$ $2,628,000$

$7,618,000$

So we see that the money-value of the chief agricultural products exported from the many states named, was fourteen millions of dollars and considerably exceeding one half more in 1503 , 1804 and 1805 , than in 1822,1823 and 1824 . Tho value of the rice exported bears fully the same proportion in favor of the earliest years. There are no specialities in these selections-for the carliest and the latest years given in the table are offered, and almost any one of the early years compared with another of the later, will shew the same general fact.

With these results before us, it is perfectly plain, or, indeed, self-evident, that the numerous people of the grain-growing and grazing states enumerated above, and containing about threefourths of all the people of the United States, could not possibly depend upon the foreign demand. for their surplus productions: hence it was indispensable to their existence, perhaps-at least, to their reasonable comfort, (which no human laws can rightfully deprive them of), that they should turn their attention to other matters-and they kave vested, probably, about 300 millions of dollars in manufacturing establishments, in the breeding of sheep, and in commerce and navigation, and the fisheries, to employ their surplus population, and give bread to the hungry. The present annual value of the products of sheep, because of their wool and shins only, is about twice or thrice as large as that of all the flour or tobacco at present exported, however much the latter arficles engage the national legislation and public care, because we have been accustomed to look at things abroad and disregard those at home. We do not speak wildly. There are about fifteen millions of sheep-and them increase, wool and skins may surely be estimated at fifteen millions of dellars, which is considerably more than the average value of all our flour and tobacco annually exported for the last three years. Ought not this matter, this "wool-gathering" idea, as in derision it may be called, in respect to the home-trade and home supply, to sink deep in our winds, whec 
We compare it with the (wo cREAT staples of our foreign trade and foreign demand, for the protection of which latter, or either of them, we always stand as prepared even to contend in battle? It would be well for every person to enquire, in the secret of his own heart, why these things are--why it is that we despise, or neglect, that which we have within ourselves, while we support ministers abroad and maintain fleets of men-of-war in the most distant seas, to defend by argument and arms, interests that yield so small a comparative profit, when we bare reference to the amount received for flour or tobacco exported? We complain not of this defencewe wish it continued and extended as the case shall require; but we cannot see why property and products at home should not have the same fostering care as properiy and products abroad? If a tariff, which shall protect the growers and manufacturers of wool, and the scores of millions of dollars vested by them,* may operate as a tax on other parts of the community (which, however, we do not admit that it would), shall not these say also, and with certainty, that they are taxed to keep up feets in the Mediterranean, West Indian, South Atlantic and Great South seas, to protect articles exported of much less annual value than those which they produco and possess within our own land--and ask why, peculiar privileges or advantages bare been granted, or are continued? If they so ask, what answer must be given?

Further-much fear is expressed of a loss of the British West India trade,-and a shutting of the po: of Cuba would throw us into great alarm, because of a restricted demand for our flourand ye ne New England slates receive from New York, Pennsylvania, Maryland and Virginia, a much sreater quantity of four than we export to all the West India Islands. Those states import. from their sister states, more than 625,000 barrels a year, besides large quantities of corn-the whole foreign export of flour was only 813,000 barrels in $18 \% 5$, and 858.000 in 1826. New England is enabled to receive and consume this great quantity because of her manufactures-more than 281,000 barrels were received at the single port of Boston, of which 72,000 were exported, leaving 209,000 for consumption, chiefly from Maryland and Virginia, in the last year; and the latter, of itself, is almost equal to the whole export of the U. 'tates to the British West Indies and Cuba-which, in 1825, was no more than $2: 23,000$ barrels Horv small then, is the foreign demand compared with the home market, for the growe; of grain? And if we allow to the people of the United States a quantity of bread stuffs equal only to "a peck of corn per week," for each individual, the whole consumption will be about 150 millions of bushels a year, equal to 30 millions of barrels of flour, (allowing five bushels of grain as equal to one barrel of flour), while the export is less than one milion of barrels. Why, the horses and hogs in the United States annually consume more than five times as much grain as would be equiralent to the quan. tity of flour exported! The foreign demand, however, even for so small a proportion of our breat-stuffs produced, is cxceedingly important, because of its effect to establish a selling-value for all the rest. But we have not time to descant upon the operations of scarcily and supply; and besides, their principle has often been shewn in this work. The surplus, or want, of a simall quantity, every body knows, has effect on the value of a whole quantity in market, to diminish or increase its price. And if we compare the amount of the animal food exported to that which is consumed at home, how will the account stand? Admit, that half a pound is used or wasted, for an individual, per day, the aggregate is 2,160 millions of pounds annually - whereas the quantity of beef and pork exported is only about 28 millions of pounds; thus, the vegetable food consumed at home, by man and beast, is thirty-five times greater than the amount exported, and of animal food, also the product of agriculture, eighty times greater, under the most reasonable allowances that it is possible to make; and which are advanced not as being the real amounts, but as reasonable dicta, to assist in forming general and important opinions. It is perfectly evident then, that the grain growing and grazing states must establish and keep up a homemarket for the commodities of their agriculturalists - for the amount which the foreign market will receive is, in bread stuffs and meats, together, less than a hundredth part of their aggregate products, and, to our whole free population, would yield not much more than one dollar, a jear for each person. Can the farmer, the man who cultivates his own field, depend upon this for all the supplies which he has to purchase, for the payment of his work-people and taxes? Pshaw?

*The property vested in the wool-growing business bas been thus estimated:

For land, - - - - - - - - - - - $\$ 20,000,000$ sheep, - - - - - - - - - $20,000,000$

$40,000,000$

which is much under the real amount; and the annual product is $\$ 15,000,000$ a gear, as atated in the text.

fit is very probable that the starch used in our manufacturing establishments consumes a greato cr value of the products of agriculture, than the amount of all sich articles consumed, (cotton and tobacco, excepted), in Great Britain and Ireland, Russia, Prussit, Holland, \&rc. We are not joking. We see it stated that five factories near Springfield, Mass. annually use $40,000 \mathrm{lbs}$ of starch. It is ascertained that at one factory in Massachusetts, employing 260 hands, 500 barrels of flour were consumed last year. Mr. Mallary stated the latter in his masterly speech, on the woollens bill. 


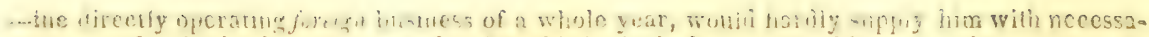
ry money for the business of a week. Let this be looked into. Nothing more than a momentary application of the self-endimt facts which we have suggested, is weediul to convince ans one as to what is the real state of things.

There is another point of riew, however, in which this subject should beconsidered. At pre-

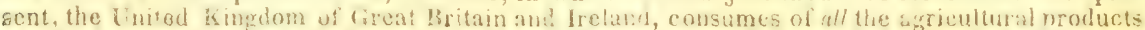
of all the etates noetl of the Putomac and Ohio, a les: value than suo dollars a year! through the people of these states comsume or purchase. Wi her manfacturers to the value of about twenty-

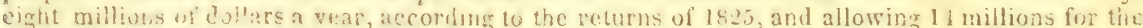

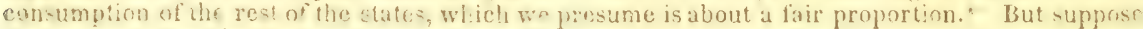
there was a little of realily in the uretensions of Mr. Huskisson as to "free trade," and that the British ports were opened only for the admission of bread-stutis. It is reasonable to believe that such proceding might atrance the price of flour nne dollar per barrel. This increase of price would be laid, of course, on the whole quantity sold by the growers of girain-which is pretty nearly equai to 15,000 ,ono barrels-their matis would, theretore, be increased in the sum ot fisteen millions of dollars. I beseech the farmers to louk at thic-the proposition is, in its own nature, as sure as any that can be diawn from "holy writ." And are they to be gulled ard cheater?

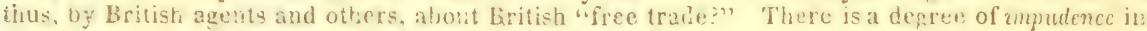
the prosedinge of these mer that in intolleratle. Ant can the farners support a trade which. (directly), does nothing to support them-which stands as fife humlred dollars cxported and cunsamed tutumligh milions importen? I have hardly patience when 1 thint of those who gravely resist whatever may tend to remove this outrageous inequality.

In slutisticat stabjects, it is capecially necessery that the writer shoult he ascisted by the consideation of the reater; indecd, he must measmab!y rely upon it. else tle details would be tediou? and dry beyond all bearing. Etht sume aplintis percoit ma ask-how do the grain-growing states bear this inciuality in their thate witl lifeat Bratail? the answer is easy: by the invaluable êrade which they have with me anohicr, and with the rest of the states, and they with them. and by that enjoyed with othey tations than the British. What sea is not vesed with our indus. sy, what purt which is opencd fo us is not frequented, if therent we ean diapose of any conmotity. the avails whercof will etable us to my Britain for her good:? We go over ali the warlu to gather profit, and cast it into Eritain's lap. But we shall at some future period, shew these things from official documents. The facts, however, are as stated and cannot be denied.

'the growth of weel, hemp and tha. and of alfer articles, must be resorted to by the farmers.

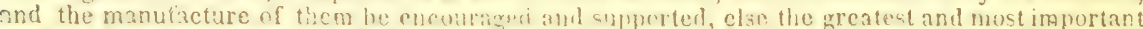
brateh of busiuess, the agrindimal, will tail wo produre a ruasnable profit to land uwners and ahose who till the soil; and a romnarative state of want, (in the present rondition of snciety), trecome the portion of this chosen ard peculiarly valuable people-the free cultivators of their owon lands - the best depository of the morals, the rights aud the liberty of their country-the. class

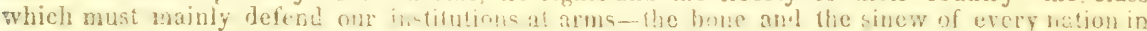
the world. And besides, are their forests and their mines, the gifts of Gon for the benefit of his creatures, to remain useless and valueless, because their products, in a rude state, are not required for FOREIGN exportation? Nu-no, they have a "naturul and unalienable right" to make

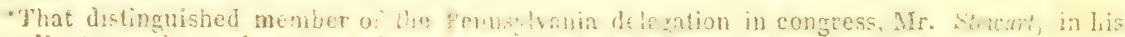
excellent speech on what is called the "woolbill," spid-.

"The plain questiun is now, shall we abandon our mamfactures and our agriculture, and im.

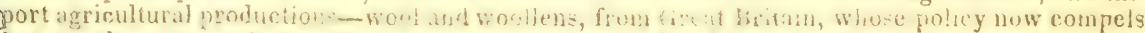

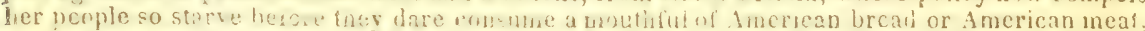
though it were offered to them for nothing?-it is made by their laws a penal offence to do so. This is the quesion. TYe are ioled that we must buy from lifeat Britain, that she might buy finum us! How is this? Great Britain buy from us? What loes sle buy from the middle and northern states? Nothing. Great Britain from whom we bought in 1525 , upwards of 42 millions of merchandise-- $10,699,000$ of it wool and woolens, took in exchange of the agricultural produce of all the states north of the Potomac and Ohio, an amount less than 800 ! and yet se are told by

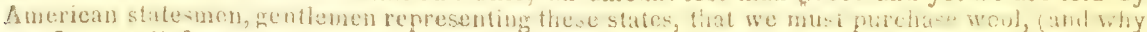
not flour too?) from Great Britain, 10 induce her to purchase from lis! I reneat it, aud I defy cantradiction, for it is proved uy our records, that in is 25 , the whole exportations into England,

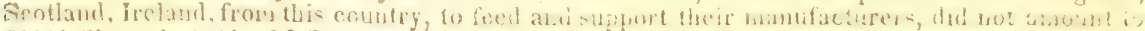
$\$ 200 !$ Sir, only 151! Of flour, rye, corn, wheat, oats, pulsc-and every other species of grain, \$ss! Of all kinds of animal food-beef, pork, Sce. \$34! And of sll kinds of drink-whskey, gin, beer, cider, \&c. $\$ 29$ ! With these facts staring him in the face, the British minister hinself would blush to ask the grain-growing states of the union to "buy from them, that they may buy from us." Sic, I would say when Grea, Britain resorts to prohibition, I will counferval her policy by a like resort to prohibition. If she prohibits our flour and provisions, i will prohibit her wool and woollens. We can live as iudependently of her as she can of us. If ste will take but $\$ 151$ worth of our bread and meat to feed her manufacturers, I will tale but 5151 worth of hor wool and woollens. I will goto New England or Steubenville, and buy from those who will buy froms me, and who will gladiy give us cloth in exchange for our provisions and wool. pers note. A. 


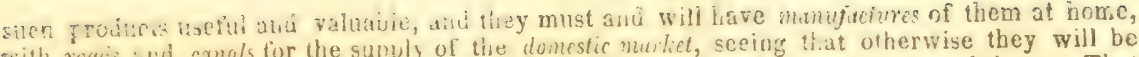
spith restis ald crmals for the sumply of the domestic nutiet, sceing that otherwise they will be (Wositerei as rejecting the bounties of heaven, to their own misery, degradation and shame. That. little vork, th:e improvement of the navigation of the Schuykill, in Fennsylvania, will yield a greatar annual noney-protit, for cual and iron brought into use by it, than the whole foreign export of $t:$ : state af ords to the incalculably valuable body of freenen and farmers in that powerful con,:onwealth. Those great woiks, the Neiv lork canais, by opening ways to the market, are, or suon wilibe, is the actual production of nore profit to the ?and holcers and farmers of ivew York and Vermos:, Ece than the whole value of the products of acriculture exported from all tho states, east and west, loeated north of the Poiomac, and containiag a large majority of all the peop!e of the United states. The irade which quietly pasaes down the inszieliannah, in the products and property of furmers and otise land owners on the shores of that river, and its tributaries, and which chiefy centers at Baltimore, thongh the navigration is hazarlons, is of itself equal to about one-half of the whole value of domestic articles exported from baltimore to fow reign places; which ircludes nearly all the Maryland tobaco, witil a considerable ciluutity fiom Ohio, and large sumplies of flour, \&ce. brought by land from the adjacent parts of lernsylfania, Virginia, \&c. These things are seriously asserted, and we are sure that they are substantially true. Similar cases might be multiplied without end, to shew what is the home marlet eompared with the foreign one, and how insignificant the last is, exeept as a regulator of the other, tr about seven-cighths, perhaps, of the neople of the U'nited States who persona!ly till their o:wn ficlds. The lides of their cattle, when manulactured into leather, are worth much more than the part

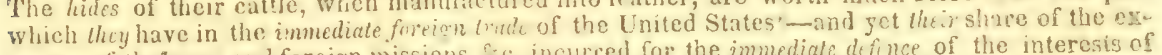
penses of the"navy and foreign uissions, Ec. incurced for the immediale defince of the interesis of that trade, is pretty nearly, or about, two millious of disllars a year. Eut they pay this trix chcer. fully-as well from patriolic pinciples as firis sel!-interest, well linowing that whatever givea profitable employment to any portion of their countrytien is beneficial in waking a wartet for themselves.t [See note B.]

We shall now proceed to speak of the cultivation of tobacen-which is chicly an artiele for export, and of two very different qualities, "Naryland" ard ".irginia," as thty are commonly denominated, though made in smaller parcels in several other states.

The produce of this article was greater before the revolution ttan it is now! Cven in 1758 , 51 : rgland and Virginia, alone, exported 70,000 hlds. and in the tiree years 1791,1792 and $176_{1}$ [see the table], we exported 273,647 , but in the three years 1922,1523 , and 1524 , only $250,06:$. notwithstanding the great increase of laborers. But the forcign marlet will not receivo r.ve than a certain quantity - the average of the Baryland quality, used f:r smoking, being shr.: of 20,000 hhds. and that of the Firginia, chietly used for chewing, less tian 50,000; and auch is the peculiar condition of this commodity, that 90,000 hhds. exported will produce no more $m f^{\circ}$ in an average, than 81,000 ! This is a curious examiple of the cffect of scarcity and suppt. and we; speak understandingly, as will be seen by a reterence to the table, made up fron ....:ia? documents-iake the following examples of succeeding years:

"Catle. The last ecnsus of N.J ork, shews that, more than a year ago, there were $1,513,421$ neat cattle in the state-- the like of Ohio gives $25: 2,544$-together for these states $1,765,965$. Such dala justify us in believing that these amount to $7,000,000$ in the grainegrowing and grazing states, already recapitulated. Pennsylvania had 612,995, returned in 1810 - seventeen years ago; ard they are very numerous in the New Engiand states. But the preceding are all the official siatements that we recollect to have seen, and, while it is hardly possible that either could have exceeded the real amount, every probability is that each fell short not less than a fourth. So our colculation appears to be a safe one-and far within the actual amount. Supposing that calces are included, the whole stock is renewed about every two years. The "manufacture of hides an 1 skins," as stated in 1510 , were valued at $\$ 17,935.177$-and the value returned of business done in the tanneries of the states referred to in the same year, $(1810$, was about seven millions of dollars-millions sizort of the then actual amount. The returns are so imperfect, as any one will perceive on inspecting them, hlat, though they licep us from going too low in our estimates, they only partially, inleed, assist us in riseing to the real sums. We hope better returns herenfter. Sce Register, vol. Vh, page 3z3, Ec. for those of 1910 . - Those of 1920 we have not published and hardly ever refer to-for the act of congress so stinted the allowance for this service, that the facts stated are altogether useless for general purposes.

fIVe meet with the following paragraph in the newspapers-

"A Mr. Wimmel, of Berlin, Prussia, (a brewer), has discorered a method of obiaining twenty gnomds of good chrystalized sugar, from a Prassian bushel, (about 93 pounds), of wheat. The Paris papers consider the discovery of immense importanee. Nr. IVimmel has applied to the French government for a patent."

Now, if this is true, and the process be not very expensive, a considerable source of profit is offered to numerous wheat-growers of the interior of our country, in which four bushels of wheat, or 240 lbs. will not pay for tiventy pounds of sugar; and the residuum, after the saccharine matter is estracted, would feed and fatten cattle and hogs, which might be made their "own car. riers to market." 


\begin{tabular}{|c|c|c|c|c|c|c|c|c|c|c|c|c|c|c|c|c|c|c|c|}
\hline es & & 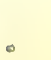 & $=$ & $\Leftrightarrow$ & & $=$ & 0 & & 77 & & - & & . & & $=$ & & & $=$ & \\
\hline & - & - & & - & - & - & & - & 86 , & - & & - & & - & - & & - & & 6 , \\
\hline & & - & - & - & & - & - & & & & $=$ & & - & & - & 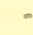 & & $=$ & \\
\hline & - & - & & - & - & $=$ & & - & & - & & - & & - & - & & - & & -12 \\
\hline & & - & - & $=$ & & - & - & & & & - & & $=$ & & - & & & - & \\
\hline & - & - & & - & - & - & & - & 99,009 & - & & - & & * & - & & - & & 6,289 \\
\hline
\end{tabular}

rirginia, which, more than any other state in the union, deserves to be called the "land of sieary habits," may long extensively continue the cultivation of tobacco, though cotton is rapidly superseding it in the eastern part of that commonwealth, of which we shall more particularly apeak nelow. The product of tobacco has declined in Kentucky, the Carolinas, Georgia and Louisiana, not being found so profitable as other agricultural pursuits; and, perhaps, when the labor and capital employed are considered, it is the least profitable of any other business in the United States, as it is carried on in Maryland and Virginia, because of the costly lahor of slaves; and it has also powerfully tended to retard the progress of inpulation and wealth in these states, by exhausting the soil and driving away free laborers. Virginia, late in the first rank of the states, stands the fourth in effective population, and, by the census of 1940 , will probably be thrown into the sixth grade; and in regard to actualiy operating wealth (which begets wealth), much further behind than that, unless her policy is changed, though her territory is so very extensive and much of her land is of the best quality. But truths like these are offensive; and we wish to appeal to the reason of persons without exciting their passions; and, after one or two further remarks on the cultivation of tobacco, we shall immediately speak of Maryland, our own state.

The following shews the value of tobacco exported in the years given:

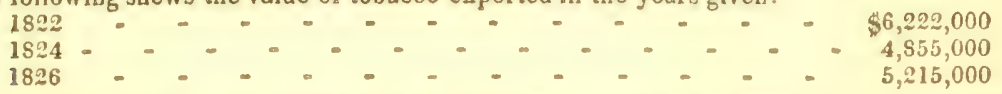

The annual average value for the last five years was about $\$ 5,500,000$-a Iess sum than that of the manufactured articles exported in the year just ended.* The first is stationary or declining, the latter rapidly advancing, and very soon to become, after cotton, much the largest item in ou foreign trade. The simplo mention of those facts, exposes the fallacy of the arguments made against the protective system, which, after suppying the demand at home, as to its chief amount for such goods as are protected, has, already, a worth in like articles exported, (to meet the competition of all nations), surpassing that of one of our great staple commodities, and of which, by soil and climate, and through custom, we have something like a monopoly?

But it is to the planters and people of Naryland that we would now directly address ourselves. In 1790, we had 319,000 inhabitants and one eleventh of the whole population of the United States; in 1820 we had 407,000 , and a twenty-fourth part of the whole population-in 1830 we shall not shew a thirtieth part of such population, unless because of the increase in Baltimore and the other manufacturing districts. Indeed, if these be left out, our population is probably decreasing. In the first congress we had six members out of 65 -now we have nine out of 215 ; and, if the present whole number of members is preserved after the next census, wve shall hare but seven; and so, from the possession of one eleventh part of the power of representation, we have passed to a twenty. fourlth part, and are just passing into a thirtieth. [The same operation has taken place and will act upon our neighbor Virginia-though her western grain-growing and grazing and manufacturing district is doing much, indeed, to keep up her standing, and would have a mighty effect, if less restricted opinions prevailed, and a really representative government were allowed "Truth thus speaks to us "trumpet tongued"-yet we scein neither to hear or heed it; and what hes been our chief commodity for export, and furnished the chief means of purchasing foreign goods, (which we have so much preferred, and which the people still blindly wish to see introduced), is about to fail us altogether! Ohio has alrearly materially interfered with ox tobacco, and raised by free labor, can afford to transport it 300 miles by land, and yet undersell our planters in Baltiwore, their own local and natural market! See the article from the "American Farmer" which is annezed. The tact is, that most of our intelligent planters regard the cultivation of to bacco in Maryland as no ionger profitable, and would almost universally abandon it, if they knew what to du with their slaves, for many reject the idea of selling them: others, however, are lesg scrupulous, and the consequence is, that great numbers of this unfortunate class are exported to otber states, the cost of their subsistence being nearly or about equal to the whole ralue of their production in this. But Marylard is abundant in resources, if casting away her prejudices, "the old man and his deeds," she will profit by her natural advantages. We have good lands, ans

*They are thus statod-in is:1 $r \begin{array}{rr}\$ 2,754,000 \\ 1822 & 3,120,000 \\ 1823 & 3,139,000 \\ 1924 & 4,480,000 \\ 1825 & 5,700,000 \\ 7926 & 6,000,000\end{array}$

$$
\star \text {.. }
$$


Auch waler power on the western shore.* The last is consilerably improved in Cecu, Baitimor Frederick and Washington counties, and monufacturing estahlishments are pretty numerou's and respectable; in all these the population is increasing-the farmers have large barns and wels filled granaries, and with markets at their doors, as it were, forthe etsief part of their surplus products, including butter, eggs, vegetables-the hundred little things which the good farmer anu prudent housewife collects and saves, and in many cases they, alone, because of the market for them, sell for more moncy in a year than the whole surplus crops of wheat and corn raised on plantations cultivated by eight or ten slaves, for they themselves eat much, waste more and work. little. The whole crop of Maryland tobacco may have an average annual ralue of $\$ 1,500,000 \ldots$ and this is below the clear product of lalor employed in the factoris of Baltimore alone! We do no: include the employment of mechanics, properly so called; and thus, aided by some foreign commerce and navigation and a large home trace, we have, in this small spot, collected and stibsisted mor: than one sixth part of the gross population, or about a fifth of the whole people of the state--and created a market for the products of the farmers, daily cxtending in the quantity required and prices given, and to go on as our manufacturing establichments prosper and persons are gathered together to consume the products of the earth. But to the success of these, and the consequent well-being of our farmers, a liberal encouragement of them, and a manly support of internal improvements, must be afforded. Whoever stands opposed to them, is opposerl to the best interests of Maryland - for increased attention to both is the only means that we have to prevent ourselves from sinking vet lower in the scale of the states. Maryland, without any sort of interference with other pursuits, might subsist two millions, or more, of sheep, and the product of these would compensate any loss to be caused by ceasing to cultivate tobacco; and besides, and what is more important, most important, indeed, it would prevent the actual or comparative decrease of our people, keep the free la. boring classes at the homes of their fathers, and mightily advance the price of lands and add to the general wealth of the state. Real property, of every description, except in the districts spolken of, has exceedingly declined in value, and, indeed, in some parts of the state, is seemingly "without price." If slave-labor ever was profitable with us, it no longer is so-it does not yielit more than 3 or 4 per cent. for the capital per capita employed, if eren that-this is clearly prover by the export of slaves to the more southern states; a cruel practice, and which we hope may be arrested by the introduction of new articles of agriculture, such as the breeding of sheep, and the cultivation of flax and cotton, and the rearing of the silk worm. These would atford employment to many thousands, and employment begets employmen:, and money begets money, for prosperity begets prosperity.

But let us further, and for a moment, rezard Baltimore as a market for the farmers of Maryland - for we wish the home market clearly understoood; most persons know no more of its real value than they do of what is happening in the interior of the earth-and it is the interest of others to prevent inquiry or mystify facts. We are about 70,000. Allow to each person vegetable food equal only to "a peck of corn per week," and we shall appear to consume 910,000 bushels of grain; if we add what is required for the support of horses used for draft, \&c. the whole may be moderately estimated as cqual to one million of bushels of wheat, per antum. Then suppose we admit that eacb person wastes or consumes half a pound of animal food per day, as we think that they $d o$ and more, and we shall have 25 millions of pounds a year. We also annually re. quire for our families, work shops and factories, more than 100,000 cords of wood. L.et us see what these three articles, these three only, will amount to-.

$1,000,000$ bushels grain at 1 dollar

$25,000,000 \mathrm{lbs}$. of animal food at 4 cents.

$1,000,000$

$1,000,000$

100,000 cords of wood (sold at) \$2 95

$$
225,000
$$

$2,225,000$

And, at these very low estimates, it appears that the Baltimore market, because of the bread. atuffs, animal food aud fuel consumed therein, annually amounts to more than two millions and 8 quarter of dollars; or one fourth of the whole value of all the bread stuffs and meats exported frors a!l the United States.

Previous to entering upon a more general and particular examination of our great staple for export, collon, we shall notice one product of agriculture which has a most extraordinary character and operation, indeed-not on exports, but on consumption; we mean sugar.

We see it lately stated in the papers that col. Dummett, of Florida, has made thirty hhds. of sugar from cane raised on thirty five acres of land-say, only $30,000 \mathrm{lbs}$. The duty, or tax, upon which, if imported, would be $\$ 300$; and this a $\boldsymbol{P}$ ennsylvania farmer would, of itself, esteem a neat little profit on the cultivation of a whole farm, for a year. But such are not so farored by soil and climate, and the bounty of the general government.

The sugar crop of Louisiana is about 10,000 hihds. (less than 10,000 in 1810 ), or, say $44,000,000$ bs. the duty on which, if imported, in excuange for bread-stuff, \&c. would be one million three

* We have also many valuable mines and minerals, which, though rapidly coming into use, are yet only partially worked. Large quantities of iron ore are carried from the neighborhood of Baltimore to the New England states, there manufactured, and probably brought back again and sold bere to purchase or pay for more ore! 
smbuted and twenty ti.onsand doliars, and this is probably divided between less tuan two hundred persons-or, if we allow it to benefit all the people of Lowisiana, is more than sixteen dollars per huad, for every man, woman, and child, of the state, as a "bounly." Now, a tax equat to this on all the people of the United states, would produce a retemue of nearly one hundred and sisty zillions of dollars a year! Verily, verily, this is "taxing the many for the benefit of the few" and yet, wonderful to be told, Jousiana is opposed to the tarifind the protection of other brancheg of domestic industry, as ealled for by the farmers and others, who make up nearly three fourths of the whole people of the United States. But this is not ali.

Sugar has become almost a necessary of life-it certainly is one of iti coinforts, desired and used by the rich and the poor. The whole anount consumed in the United States may be about 120,005,00163. Say 76 imported and 44 of domestic production. The duty on the former is $s$ cents per 1h. and crmounts to $2,280,000$ dullirs, on what costs about five millions in the foreign sslands and plices wherein it is obtained; so that the tax is rery nearly firly per cent. ad vulortm. which is actually sollected on two thirds of the whole quantity used, to the henefit of those of ous" own countrymen who proluce the other third. And yet louisiana declaims against "monopolies" und the tariti which sipplies her with such cotton gouds for 121 cents per yard, as lately cost her 20 or 25 cents per yard!

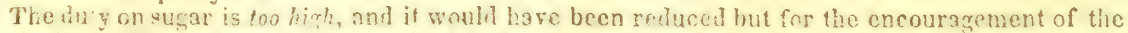

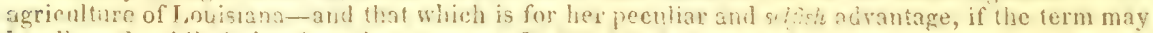
be allowed, while it denrives the treasury of 1,320 , oun de liars a ye $r$, taxes the people in the sura of 1,1 in,000 dollars annully, more than they weilh pay, if the ditp was reduced nnly to two

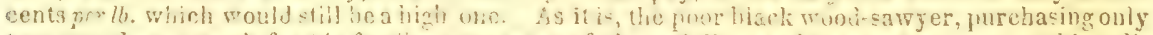

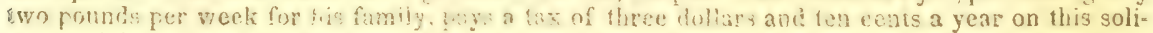
tary article. It is the most onerous tax that we have, and bears particularly hard upon the laboring classes, especially the farmers, mechanics and manulacturers. We ourselves use as

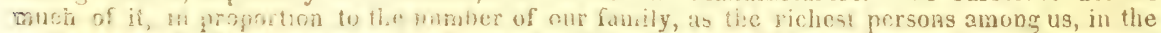

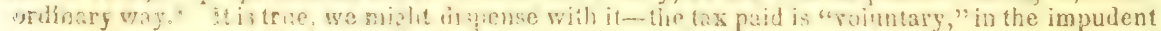

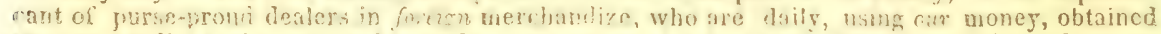

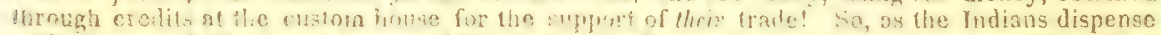

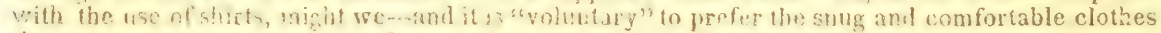
that we wear to tise ?

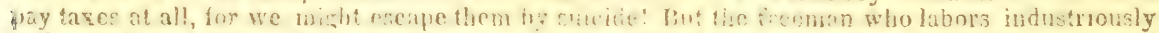

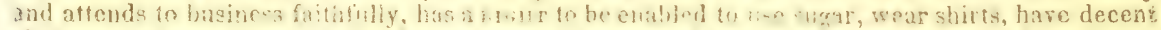

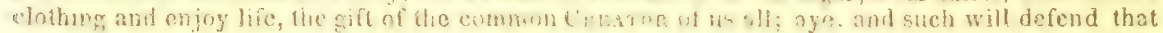
right: and, what is worth a whole volume of speculations, they have the means of doing it! The

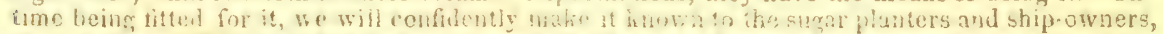

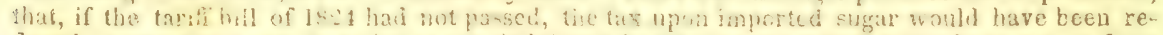

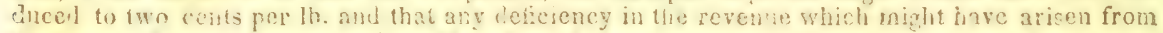

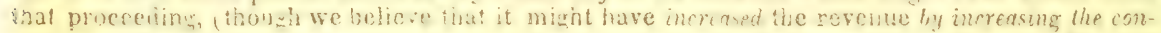
stmption of surar), would hare been more than compensated for by withdrawing the fleets of

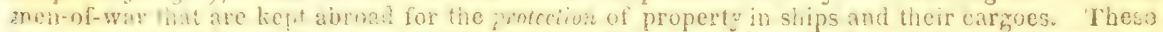

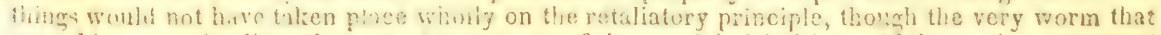

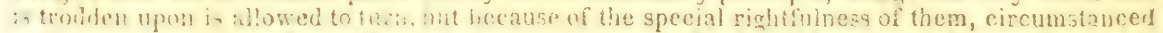

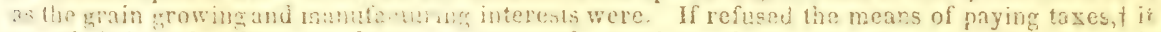
was their bounden duty to reduec the amount of tases demanded. There is a quid pro quo which operates in every condition of life; and, as the saying is, every prudent man will "cut his coat accolding to his cloth." Look at it!-here was Louisiana receiving a "hot-bed protection". of

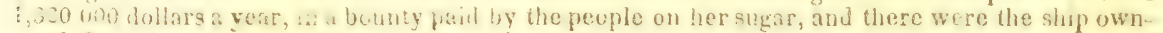
ers lefended at the canrion's mouth, at the cost to the people of a much larger sum-the vohole

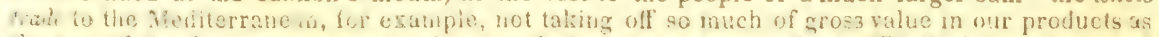

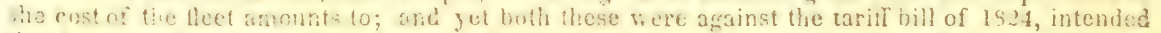

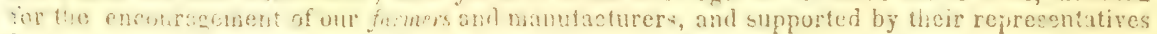
in congress, as the votes will yet shew! We would not either "razee" the duty on sugar, or "toma-

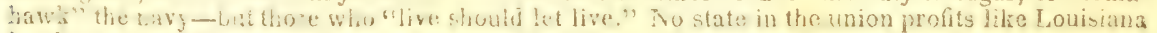
by the tariff- the price of her cottun is assisted by it, as we shall shew when wo speak about

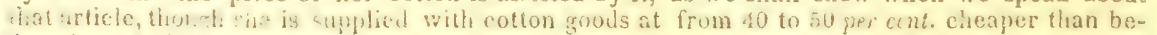

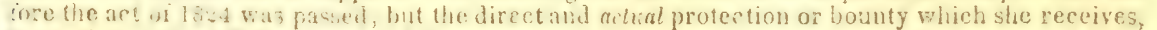

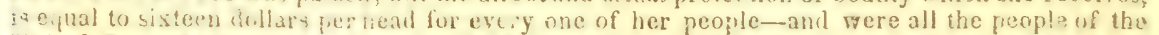

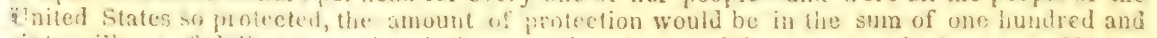

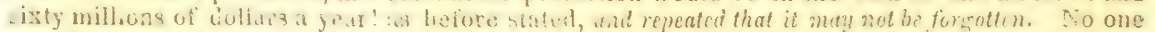
"in dispute this. And furticr, ia a "monopuly" becouse of cimate in the south, leis vilous thau

"The fanily of the writer of this, consistivg of wine persons, consumes not less than 450 Ib:. a year. The $l a x$ that he pays then on sugar is thirteen dollars and a half a year.

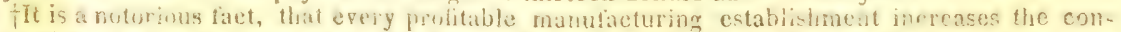
sumption of forcisn lusuries or comforts. A mantacturing village of ; ox sho penple, eon.

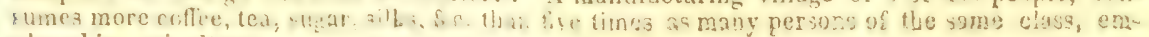
ployed in agrienl'ina. 
3 "monopoly" because of cimate in the north, on the rest, or the east? Trhat is the surarplanter better than the wool-grower? Is it not quite as necessary to have clothes to shieid 113 from the cold of our winters, as sugal to sweeten our coffee? But we desire hoth, and only ask, while the production of the last is pratected, libat the growth and manufacture of wool for the other may be encouraged; and Lonisiana, who rescives so liberally, should instruct her senators and representatives to rive a little. It is by mutual concessions and recommoditions that the peace of families and societics is meinteinew; but there is a dispositon wisely inplanted in the human mind, to require such conesstons and acommodations betreen porsoris possessirg equal rights, and it operates in gieat thin, as tLe witer of this really put it into prantire sbout two years ago in a small affair: in returur, fin my dimer, I was accustomed, almost every day, to meet a dandy Eng!ishman just impurter, (or cloperl, as the case might he), who majestira!ly strutted along the middle of the pavenent. I gave way, and went unthinkingly to the right wr the left, for a cansidrrable time; but, at last, was satisned that he lemanded this homage to his puppyism. The next time when we were about to pass, $I$ liept the millle of the parement-lie came on rapidly as usual, with his head up and eyes raised, and wholiy unprepared to receive my elhou, which he rum afsul of, (having turised myself half-round to accommolute him with it), ard he areariy fe!l down in consequence-heing a lirhter man than mysclf He looked willly for a moment at ine, I looked calmly at him, but not a word was said-we passct, and ever ifter that he coneried a part of the pavement to me, as I had been quite willing to yield a part of it to him, or any other pereon, though black and a slave. This familiar case, will arve as well as the most elaborale one that could be stated, to shew the principle on which society is sustained.

We shall now present some facts and opinions bearing uron the preacut creat stanle of oul country, cotton; whatever belongs to it is fill of interest and lishly impotant lo eve y section

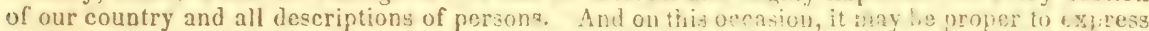
our serious belief, that, if the doctrines which wo have supported for so many years, bawe boen beneficial to any one class of the people more than another, that clites is the cultiwters of ert!nn. It is with much satisfaction, indeed, we obserwe that many of die plateter he: in to tiven:ar this, and that a radical change of opinion may be speedily hoped for. A litile while atgo, or three or four years since, the people of the eastern states, devoted to commerca and wurgation, were as much opposed to a tariff for the encouragement and protectnon of dotnestic manuroctures as those of the southern states now are. It has been demonsiated, that suecess in manufurtures his increased the commerce and navigation of the east, and was, also, adding rowerfully $t$. the with and population of these states. But with how much more rea:on mov it be expected tisat thoy will assist the southern states, seeing that they eren now and alreaiy consume ont-fouth of this whole crop of cotton raised in them?

We have been lately honored with many letters containing sentiments sinilar to theae in tho extract we are about to introduce, which is from nne of the mect lighly honored aid worthy grentlemen of the south, and which came to hand since this article was in preparition for the press. He says-

"There is a perfect coincidence of opinion between as on the subject of protecting liome manufactnres. Bad as the times are for the cotton planters, (of whom I an one in a small way), thoy would be mach worse, but for the demand of our manufactories for the vaw article. I shonld like to see more effertual protection extended to the growth and manufacture of wool. These and such like measures rvill in time make us independent."

The preceding is a literal extract, and the particular words are malked as iy the vriter limself: and such, we repeat it, is a rapidly growiug opinion among the people withe sonth. The time will :nme, when cotton planters shall be rnany times more ansious for a protective tariff than the cotto spinners! To the last, indeed, it is now of little importance, exrent to maintain stratims in the home market; for they meet the British in fair and manly competition ahmal, and wndersall them in erery market which is equally free to our fabricka and thein's." 'ihis is "contimatimn strong as moofs from holy writ," that, while they consume so lare a portinu of the preducts of our planters, they neither demand or receive any alvance from the sav planters on the nanutactured article, over and above what would be paid to foreigners, whether the cotton was of Americar proluct or not; but furnish them with cotton goods at much reduced prises.

ihe progress of the cultivation of cotton in the United States, i-, every way, wonderful. If - $y$ person had predicted, 35 years argo, that the crop of 1826 would have amounted to 720,000 oales, or about 250 millions of pounds, we sliould have put him down for a matiman or a focl-saying "go to the bospital, go:" if any one had asserter only fifteen years ago, that Niorth Carolina. Tennessee, Alabama, \&c. should now produce what they do, we could not have believed him; if it had been said only five years ago, that Virginia woulil cultivate and spnd into the markef nearly 40,000 bales iil 1926 , we should have isugled at the proposition and if it had bein sug-

* A commercial letter from Lima dated oet. 1, 1.226, says-bour unhleached 3-t and $7-5$ domes. rics are graining ground hexe daily, and in all cases prefered to English or India cottons. They generally command a living profit at least. There bave been samples of them sent to England fu: imitation, but whether they have succeeded we are not able to say."

Many like !etters might be quoted irom other prarts. But what a rolume of instructing is otstainad in the few lines we hape given! 
geated, that a rrop of colton shoulu he mace in Mrorgland in the last gear anany would have smiio ed at the "notion." How much further narth the cultivation will go-no one can venture to assert; but Iarylant, Delaware, Now Jeray, ast Illuwis and Miaconri, and perhaps, other states,

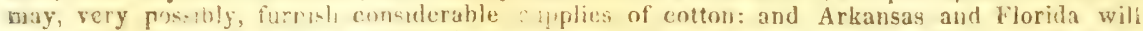

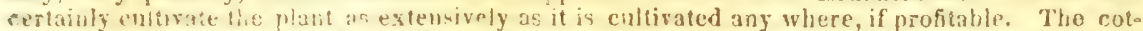
pon-producme region wi the linited states thus cmbraves a vast tract of land-capable, in itself, If cultivated as it cacily may he, sullicicnt to supply the whole world witn that valuable commouity. (li lim, and of the progress of its cultioution, the planters should take most serious nosice. Eypt is pourine out new ass large supplies for the Luropean market, and that eountry and Greces ant the cireck islands, are capable, in themselves, of supplyitig all iturope-and probably will do it, shovit the latter be emaneipated and have peace. Latior is much cheuper in those countries than in our southern states. A freeman may be hired for a little more than the anrual interest on the money rested in the person of a slave in thiz courtry; and it is cost of labor and subsintence, with the requisitions of government, that must forever establigh the cumparaijve prices of commodities. not confined to the production of peculiar climates. The immense bisland, or continent, of Few IIulland, aloo berins to furnish supplies-and the land on this shole fittel to the arowth of cotfor, is competent to furnish a thousand times more than ats peo. ple can consume; and besides, the cotion of many countries (except as to the small quantity of "sea island" which we raise) is better than our own. It is impossible then, that we can have and preserve a "monopoly" in the production or sale of this staple. Our cultivation has alraady passed beyond the mofilable domand. The crop of 1526 , compared with that of 1825 , shews an jncrease of 150,000 bales, or more than one fourth of the whole quantity produced in 1625 ? Can this increase continue? No-no-no-indeel, no!

Cutton first beaan to be raised in 1799 or 1790 , except as a a arien product. In 1791, we exported 189,516 lbs $1,601,000$ in $1794,29,911,000$ in 1801, a part of which was of foreign growth, for

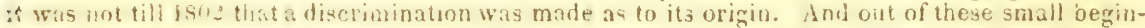

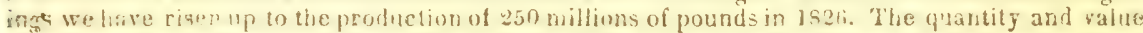
of eotton expurted has exreednniy lluctuated, and the remarks which are applied above to tobacfo are also spplicable tu it, respecting searcity and supply. The following items are interesting

\begin{tabular}{|c|c|c|}
\hline Yenrs. & Ponends. & Falue-Dollars \\
\hline 1791 & 139,000 & \\
\hline 1796 & $6,100,000$ & \\
\hline$\$ S 00$ & $17,759,000$ & \\
\hline $350=$ & $27,501,000$ & $5,250,000$ \\
\hline 3507 & $66,212,000$ & $14,33: 2,000$ \\
\hline 310 & 93,$8 ; 4,000$ & $15,108,000$ \\
\hline (1915 & $9 \approx, 998,000$ & $17,523,000$ \\
\hline 1816 & $51,7.17,000$ & $21,106,000$ \\
\hline 51810 & $87,937,000$ & $21,031,600$ \\
\hline$\{18 \approx 0$ & $127,860,060$ & $2,308,000$ \\
\hline 1893 & $173,723,000$ & $20,445,000$ \\
\hline 1924 & $112,369,000$ & $21,947,000$ \\
\hline
\end{tabular}

The vear: cunn:eted with a brare : - ) and several other prims of year that might be offered from the tahic, shew that quantity and value have no certain relation one with the other: $S 7$ millions of pounds, exported in 1519, were nearly as valuable as 127 millions in 1520 ; and 173 oilfions in 1823, proiluced 1,500,000 dollars less than 142 millions in 1924. These facts cer-

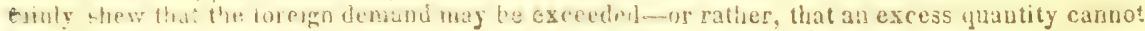
be sold? except at a rectised price.

zhe whole crop of 1826 is estimated at

$$
\text { lisio } 7 \text { is, } 0 \div 7 \text { bales. } \quad 560,249
$$

\section{Incintere in che yrar}

150,778

of the 72000 inales, we suppose that about 175,000 will be consumed in the United States, and afsat 18 a millions of pounds may be left for exportation, if the forcign market will receive it; but when the annul commereial iables are publisherl from the lreasury department, we shall be able co spesk more filly on this interestine point. It is well known that our own manufacturers were the eticf purchase's in the early part of last season. We may expect that they will require $; 50,000$ balec in from six to ten years, unless destroyed by sorne suicidul policy. When they shall reach that quantity, ahout 150,000 bales will he made into goods for the foreign market; for it is fist as cortain to our mind as any almost everg other fiture event can be, that the British manusacture of cotton must decline, and many people will depend upon this, instead of that country, for theirsupnlies of cotlon gnods. Some of the roasous for this belief we set forth in the article Futblished in the In:Gister of the 27 th January, ult.* Let us howerer look to the present only.-

- We have since met with the fullowing, from a London paper, which is not less applicable to the selation in which bingland stands to onr country than to Jatice.

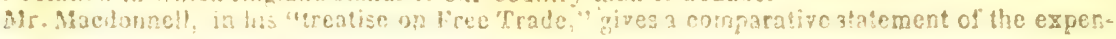


¿an any one fail to suppose that the domestic demand for one fourth of the whole giuartity produced, has no effect on the price? We think that every reflecting calculating merrhant or dealer, every one who has thought of what belongs to searcity and supply, production and denand, would estimate this demand as equal to 10, 15 or 20 per cent adrance. Indeed, the price of cotton exported in 1522, 1823 and 1824 shew this-for in these years our manufacturers were ex ceccingly depressed, and many of them absolutely ruined. Stop their mills and looms noun, and cotton, if worth eight cents, would tumble down to six; and the price of cotton goods woulil as suduenly rise, at the same or a greater ratio, and thus make a double loss to the. American people, and a double gain to forcigners. No business-man will contest the princryle of this proposition-it rests upon the natural and unavoidable rules of trade, and is applicable to all sorts of commolities. But admit that the present domestic demand has effect to raise the price of cotton oniy half a $c+n t p e r$ ib. or five per cent. On its value, and this we think that the most obstinate and resolutely blind opponent of the tariff will be eompelled to allow as being very reasonable: then, if the crop be -250 millions of pounds, the gain to the planters, because of this demand, is $\$ 1,250,000$. This item we wish especially recollected-for it will be referred to below.

These results, simple as they are, will not fail to excite surprise in many persons. "IFho "rould have thoughi it?" But such is the result of almost every investigation, or comparison, of things at home with things abrocul. I.et us usefully shew this, in a caze that is exac!ly in point. if the importations of the United States amount to about 75 or 50 millions, (whreh may be talien as an average official value of them), the vecllen, collon, finxen and hempen goods, including ALL manufactured articles of these, used for the cluthing of persons, and for all family or otier purposes in which such goods are refuired, will make up al or 22 inillions of the sanont. Now, if these clotbs and cassimeres, worsteds and stutfs, blankets and ruggs, cotton piece goods. printed, colored or white, nankeens, woollen and cotton hose, flaxen arid hempen goods-worth. in the whole 22 millions of dollars, be divided among the people of the United States, each person might receive almost two dollars worth of such gonds in a yerr-some of which, however, are not consumed, being exported. Who cannot "draw an inference" from this?- that our people would be "clothed with nakedness," if they depended on the foreign supply? The probahle value of such goods consumed cannot be less in the whole, than $1: 0$ milijons, which is about ten dollars only for every person, includiug what is required for family and other purposes, never excepting cotlon bagring!?! But such is the effect of scarcity and supply. as before severa! times alluded to, that the small value imported interferes with the whole quantity consumed-and ten mallions worth thrown into the market over the amount of the needful supply, will reflect that supply rrore than the ten millions, extra, are worth in themselves, and paratize the whul husinesc. "Every good rule worls both ways" -if this foreign excess in articles inanufactured produces such imposing effects on ourselves, what would be the state of the European market for our colton, if we exported one-fourth more than we now do? Iet cotton planters calculate it! Again, and further to demonstrate this operation, and shew the importance of activity in the market-when the late news arrived as to the transportation of British troops to Portugal, flour momentarily advanced one dollar per barrel. Now, we could not expect to send to Portuyal more than 2 or 300,000 barrels, in the present year, under any probable circumstances. The difference of ralue would have been only 300,000 dollars; but that difference might have affected the whole ralue of all the bread stuffs in all the United States-the annual consumption of which, we are morally certain, is equal to $50,000,060$ barrels of flour; so there would have been a generally increased value on crery barrel of flour or bushel of grain which yet remained in the Lnited states for consunstion, had the rise caused by the expected demand in Portugal been maintained, which was only in the sum of $\$ 300,000$ ! "He that runs may read" and understand this; no proposition in Eurlid is more capable of unerring solution. And who would regret this adsance in price to the fariaters? Supposing they consume one half of all which they produce, it would have aided -everal milions of dollars to the active circulating mediam of the country, and every man, becanse of the incrtased facility with which he might obtain money, would very gladly pay his own advance on the cost of a barrel of flour. The crsh would all be among ourselves-not a cent would be lost hy ${ }^{2}$ it. For our own part, we are perfectly satisfied that we can well afford to pay 10 dollars for a barrol of flour (that being the common selling price), better than fire, anifify cents per lb. for the cotton used in the goods which we purchase better than ten, unless the appreciated prices shall grow out of actual scarcity in the domestic production. Either would make money "pleyty," and, in the general stir of it, we should piek up extra sums, and receive extra subscribers, the extra profits by which would pay our own advances on the articles named an hundred times over. And thus it is with every person engaged in business. Uur draymen would be glad of it, and make a large profit out of such a state of things.

But further-we assert, and 35 appeal to the documents, ${ }^{*}$ that the whole value of all the

diture of a London mechanic, with a wife and four children, and that of a Parisian mechanic with the same family. That of the one he estimates at $78 l$ per annum, and of the latter at 45 l. 10s. Of the excess of expenditure in the case of the English laborer, (viz: 32 . 18s) he atiri. Jutes one eigth, (or $4 l$. 1s. $3 d$ ) to the greater amount of taxalion which is paid, directly or in directly, by the English mechanic, as compared with the tasation borne by the French artizan.

* Referring to those of $15: 3$ - the year preceding the adoption of the nreasut iarif:. 
woollen, cotton, flaren, or hempen roocia, imported, and of all the mixtures of thetw, of all sorts, sizes, shapes, colors-from the dimencions of the finest thrad, to carpets many yards wide, has an average ammual value of abont twrity two millions a year. Well-by the census of 1820 there were, say. S, 000,600 of the pery!s and 10,000,000 persons in the Lnited States. We shall, however, use the latler number to avsid the shadow of olfence on any account whatever. The whols population of the cotton groving stites and districts, (without reference to the anount of persons employed in the cultiration of the plant), may be thus roughly shewn: One eighth of Virginia One fourth North Carolina 133,000

All South Carolina

All Georgia

All Alabama

All Louisiana

All Mississippi

160.000

Halr' Temessed

490,000

340,000

127,000

153,000

75,000

221,000

1,699000

"All toid" 1,"00,000 persons, or 1,000,000 of the people of the United States. Nin let us supmose that the duties levied on the gonds above described are really [ves, really] paid to the amuunt of thirty per cent. on the reported cost, and it will appear that the whole rovenue derived from them may be $6,600,000$ dollars; and then, if we almit the $1,700,000$ per mns to pay their full and equitahle share of the whole, (which is admitted only for the salse of the argument, for slaves are not made to entribute, through their masters, as freemen do), we have $1,122,000$ dollars naid by the cotton rrowing states and distriets, on all the goods above described! and, if we allow that one fourth of the duties collected is more for the protection of our manufactures than the general revenue of government, the amount will be 290,500 dollars a year, one fourth only of the increased value on cotton because of the tariff, at the exceedingly moderate rate supposed above, and one fifth ouly of what Louisiana directly and certainiy ubtaing on her sugar, through the tariff- "the accursed tarif" article imported and consumed hy the people of the United States, which is about the sum of $\$ 2,280,000$ and would be $\$ 3,600,000$ were not the sugar of the statc just named duty free! Who is not surprised at these results? The subject might be further pursued, and we shall pro-

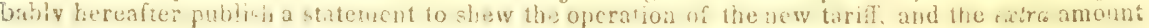
ATPARENTLY paid under it, on all solts of articles. It will amount to a small sum, indeed; but the InEALITY is, taling all the articles together, that those which have becn protected are cheaper because of that protection. So much for the las which an "honorable gentleman" in his place in congress, swore "by liecrenn, Gicoraia would never submit to!"

IVe shall now hasten to bring this essay to a conclusion.

The cultivation of colton is not now at all a profitable busiress--the rapital vested is Harge, and the product, in money, comparatively small. A IIuntsville paper of the 26th January sa"s, "the planters of . North .Hlabama vill readily agree that the prescnt price of colton will not defray the expense of cultivation, vent free." Another paper of the same place, of the 19 h, speaking of the prospects of the cotton planters, says-

"These are ghoomy beyund all furmer example, and the price is depressed beluw the wishes or expectations of our worst encmies.* No sensible man whild have ventured, fice vears ago, to predict, that uplend colton of fair quality, would ever fall belosw six cents per puund; but this sad reverse we have witnessed and felt to our astonishment and mortification. It is well understood, in cotton growiug countries, that the article cannot bo grown and vield a reasonable interest on the capital employed, at less than eight cents per pound, and that the actual disbursements, independent of the interest on the capital employed, neariy equal the present price of cotion."i

"Who are those "enemies?" They who nredicter? the prescut siate uf things, and warned the pianters against it:-who eshorted a consimption at home, to present so great a glut in the marHet abroad?

tThe collowing is from the same paper:

The leading agrienlturalists of South Carolina are awake to the importance and necessity of adopting some new culture in that state. The different agricultural socictses have formed a Uniied Agricultural Society for the state, composed of delegates from the local societies. At a reeent meeting, the following resolutions were adopted:

"Resolved, "That it ve recommerded to every member of this society, to use his best efforts for promoting, in this respective district, the culture of some staple, suited to our climate, and which reay divert the attention of plenters from the culture of collon, non mratuced in excess.

Resoiver', 'That a previum of jorty dolla's be awarded to any experimentalist who shall succeed in introducing stich new culture, on a space of ground not less than one acre."

'tinis last resolution is evidently intended to cncourage experiments with the vine and the mul. uer?:

Ii i stated, that superior specirnens of domestic wines and of homesnun osuaburgs, were pre. 
Fien follow some execllent remarks on the fluctuations in the price of cotton, and the ezcess of quantity raised, which, if much vore augmented, it is stated, will cause plantations and slaves to the a tax on proprietors, for that "the proceeds will not defray the dishirsernents," \&c. all which is very probatile or very true, and we, indeed, exceedingly reggret it: but "bard as the business of growing cutton ray be at the present time, it would be inush worke" except for the home manufacture of it-it would not yield so much by one cont per lis. though we have only supposed hulf a cent in the precerling spectulations on this point of our subject. We feel confident of this, and so the difienere to the cotton-growers would amumit to s:, 00, w 0 in the year? Examme it-it is so. "Phe liome-marhet too, is extending. A steum boat arraved at Pittsuru, a few days since from Tashville, laden with six hublred and thirteen bales! The bouse consumption is about 175.000 bales-or one fourth of the whole product. The whole anount of domestic cottons sold in Philadclphia, in the yearg 1501, 's and ' 6 , were valued at only $\$ 17,670$ : those sold the lant year were worth fou milions. We as sinerely sympathise with our brethren, the cotton growera, as with the gram growers and wool grower:3. Whatever depresses tither, irjures the whole country. There is no inrompatibility in the prosnerity of all these interests and of the manufacturing at, commercial, for ail operate to a common object. Fut I repeat at-ex:ept the surar planting interst, there is no other interest in the conntry nore benefited by the tarsin than the cotton phantine. The daty is three cent wer 13 . which speral times has, and in future will be, a proteclion, motwithetanding the export of that article, because of the very inferior gualities that might be innorled and interfere with tince grown by us. And to terninate this long essay, with otserving, that the time is elose at hand when the cotton planters of the United States will be no leas the oper and aroned friend: of the "Ameriean system" than are the manufacturers of cotton, of wool, or iron: and expressing a hope, that the three hundred subseribers in the south which we lost, within a few years nast, because of our perseverance in respect to that gystem, (though vur list is sull reepectahle ond now ou tise incretse in that part of our country), will protuce the gainctis sistumet, hecause of the good that we homestly endeavored to do, and sincerely belisverd that we were dois? to all uthers, we wish peace at:d prosperity-and hall always esteen ourselves hapny, indeed, if, while suftering what at a cort?in periul apyeared like a prscution, we can benefit those who have

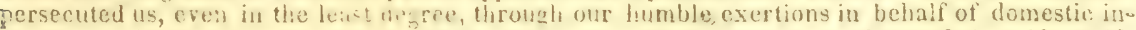
dustry, as the chief ngent to render these United States really independent of the old world,

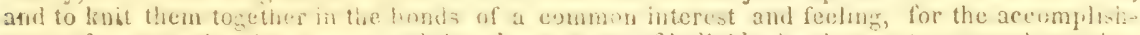

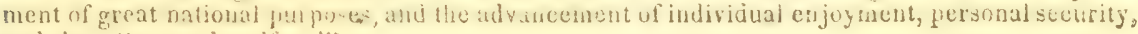
and the-"general weltare!"

NOTE-TUBACCO.

[It will be obserred that this article was written before ous mil-roul project was on foot. The buoks were opeted on Tuestay last, and though not to be closed for tell days, and subseriptions were received at ofler flaces, the anmunt of shares taken, (amd hy those who will pay for them, and generally lieep thess), alrcady inuch exceds the number allowed in the charter. Ev. Rexio

In a late number of the "Inerican Farmer," the intelligent editor, speaking of tobacen, says-

Little or none of the article, the growth of 1826 , has has yet come to this inarket, except froms Ohio. From that state several crops have been inspected, and sold for high prices. One lot of six hoggheads sold yesterday for from 12 to 13 dollars round, and the whole crop of the same plarter, eighteen hogshead's bunber, has passed inspection in the tincst order, and has averaged nearly, if not quite, 14 dollars per hundred. The perfection to which the Ohio planters, have already attaiaed, in what has been deemed difficult in the culture, and jet inote in the prom cess of preparine for market, is a remarkable proof of the superingty to be expected in every ease where the ar:tual produce is under the constant iniluenee of self-interest and the prospect ci immediate persunal proitt. That miluence, unted with the firtility of the suil, and the extranr-

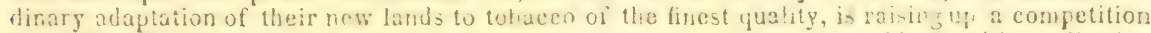
to whes the planter of the seatoard, slave-labor district, will hlib to yield, notwithstanding lus greater facilities of transporhation to markets; and if this transmontage rivalry be at thistime so

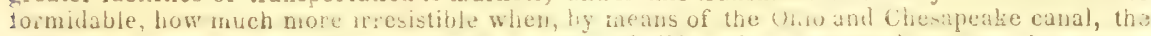
only acivantage in favor of the siave-holving phater, whall have been rewoved, and upon how many more articles will that rivalry bear? The Ohio planters, who visit our marliet, aver that whilst they cau get four dollars per lingded on theis faries, or what is the same thing, clear of expenses

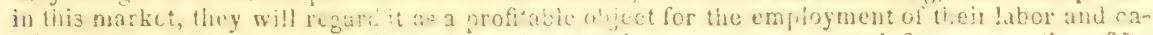
pital. The particular erops of which we have spolsen were transported from more than fifty iniles beyond Whecling, for $\$ 75$ per civt, and it may probably be assumed that the average cost

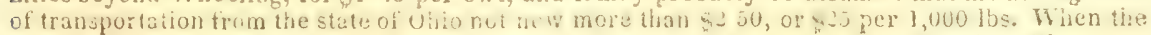
canal shall have been fuished, the cost, acecoding to the ahticipations of its fricnds, will not ex-

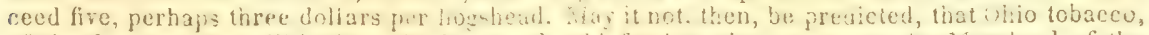
of the finest puality, will be bronght he worst? And what inust be the efieet of this upori tie price of Marylund lands? This side of

serted to the society. The planters of Alatiama should follow this exampir. Fon surely in ne part of the union is cotton such a drug as in this state. 
the picture wears truly a gloomy aspect in the eyes of Maryland planters: but are linere pot countervailing advantages in store for them? And, were there not, do they not find in their public spirit, and their devotion to the general good, an unfailing salvo for any personal sacrifice? It is known, in pronf of their patriotism, that the planters of Prince cientge's have disputed for nothing bat the homor of who should be the first to break ground in this great national work.

From Ailes' Register, of June 3, 1527.

'The following account of certain flamel manutactories is added, to shew their effect upon the agricultural interests of the country.

"Between Salisbury and Amesbury, and about three miles above Newburyport, (says the N. York American), the river 'owow discharge's itself into the Merrimack. On the Salisbury side of this stream. is a famel factory that employs 80 hands, and manuactures weekly 100 pieces flannel, and pays yearly $\$ 20,000$ for latror. On the Amesbury side of the Powow is a factory that employs 180 worknen, mat nufactures 200 piees of flannel per week, and pays annually $\$ 40,000$ for labor. A new building is creetine which will contan 10,000 spindles, and manufacture 400 pieces of flancl per week."

From the duta thus given we gather, or assume, the following facts:

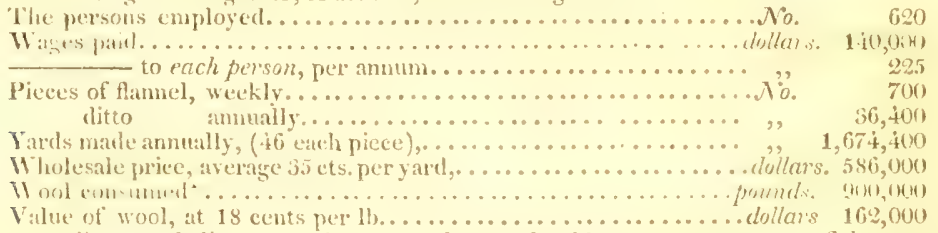

The proceling, we believe, nav be accented as a tolcrably correct statenent of the operations of that the flamel tactories alluded to, on the deate furnished. The wayes paid shew that a large part of the peresons tmployed must be alults, and these are alway numerous in and about woollen factorjes. Mitny must be heals of familie's, and it secms not morenable to conclude that their subsistence, fuel, Ee. Whe products or property of firrncis, nay amount to 100,0 (ro dollars a year:t 'The wool is worth abour 160,000 dollars, and the miscellaneons anticles consumed in or at the factories, sneh as fiel, food for lorses, Ec. must amount in many thousand dollars more. At any rate, it is quite safe to conchule, it our information be at all worthy of reliance as to quantities, and our averatges ane pretty nearly right, that these three factories tiruish a direct maket for the annad consumption of acricultural problucts to the value of 260,000 dollars a year. 'Ihou, there are supplies of brick, stone and lime, timber, glass, Ee. de. for the factory-houses and the many other nez buillings neessary to accommodate so many peoplo -then come the masons aud earpentirs, se. to ereet and turnish them, the iron makers, fee. to supply materials, and the workers in metal and wood to make the nachinery; and afl these, and their families, are fed, and enabled to pav for articles eonsumed loy them, through the citpital invested and employment stuplied at these establishments. Further, the tratusport of the various mecessaries for these peopleand the materials used by them, with that of the croods manufictured, must ronstantly emuloy nany tons of shipping and many wagoners, wagonsand horses, Se. and these agrain nust be supported aul subsisted, and are so by means of these factories, for which it will apperar there nust be sulficient resources, because the work-people and wool-errower's being paid, there will vet reman 282,000 dollars at wa for ather expenses and profit on eapital. But it would require a minuteness of detail that might be tedious, (if we fielt at) to give it), to shere the whole extent of the business and profit accmins on uccount of these avarks: sufficient, however, has been sail to assist those who ale pleased to thinh on suljects of this sort, to disecru what a range of business urrows out of sueh establishments. Now, if those flamels were made in Old Fingland instead of $N$ (ew England, this whole business wouhd be lost to us, and we shonhl hare to pay to Englishmen the whole value of the goods in eash, while losing the whole value of them at loomeas, because of this operation. Engrand would not keceive of as one dollar's worth nore of any of the produethons of our eroune, not even of eotton, than she now does-ton she takes nothing which actual nudiscruised necessity does not impose upon luer; no one thing that she ean make or procure with herselt: chourh at nuch higher prices than we could and gradly would supply it at.

We think it wrobable that the three tactorits spoken of subsist in wares paid, compensations allowed for services varins ly rendered, or interest on erpital, more than two thousud pertsons; and the whole produet, (5\$6,000 dollars), will allow for each of the 20om, adults and childten, an arverage sum of 293 dollats: and we conchule that at least one half of the whole sum would not lave been eaxned but because of these factories, as numbers that are made producers wonld have pematned among the consuming elasses, and the value of many of the materials used would uot otherwise have been aseertained. Mines of gold or of enal, ace both and equally valueless without labor-which is the first principle of

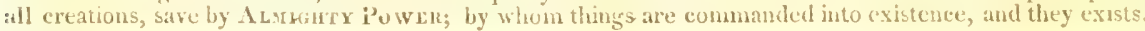

* Furnished in the roush, or but partially eleaner?. TVe do not pretend that this item, or that which folIows, is entirely accurate, uot having practieal men to consult-but they are sufficiently near it, for grenedal purposes. 'The difference hetween the weight of pareels of wool purehased of the finmers and ot thr cloth made out of it, is rery larse. The waste, we are told, often exceceds fifty perp cent.

the people employed in these works woukd be subsisted thotwh the works themselves were notbut rot so plentitully; and the benefits derived from the circulation of the money carned and expented by then would be natcrally affected. Besides, and which is most important in the special eonsideration of this subject, but, for this employment, many of them would be engaged in the production of acrieultur Fal articles, and increase instead of consume the surplusecs wanting a market, and reduee the value of stiv uhule of tlitur. 
From Niles' Register, of Tune 9, 182\%.

Vingraia versus Pennstuania The greal cause of "Virginia doclines" vs. "Pennsylyania m'urtices," is again to be argued before the people of the United states By adhering to the for mer, Virginia has advanced the number of her people 160,060 in 30 years, from 1790 to 1820 ; and hy the latter, Pennsylvania has increased her people 625,000 in the same time, or more thas all Virginia contains; and the wealth* of the latter has proportionably arlvanced. Thus--
3790 .
People.
442,117
1820.
l'eople.
$602,9 \div 4$
429,099
$1,049,398$
1830.
(Calculated )
630,000

Virginia

Pennsylvania

The first periol shews a difference in favor of Virgınia of $13,000--$ the second in favor ct Pennsylvania of 447,000 ; and the next cenaus will increase this balance to 650,000, or moteand the people of the United States, located in Vennsylvania, will be more than twice as numer. ous as those who shall be located in Virginia-yet the latter tas fifty per cent. inore territory. and a much larger quartity of good land than the former, and is, in every lespect, as well fited by Provitenre fir the comfortable subsistence of a deuse population of industrious and enlightened citizens. Lut our proment intention is only to mention these things. We desigg soon to puthlish certain tables to bring out the statistics of the two states in bold relief - that "he who runs may read" the diference between "Firgima doetrines" and "Pennsylvania practices." We are not, however, disposed to fuarrel with Virginia hecause ler great men prefer

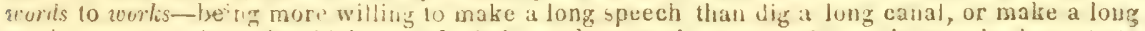
road-io wrice atout he thickneys of a hair, and prove that a mmorily ought to rule the state to preserve its "republican" character, insiead of protucing any thing of the value of a hair, or in any wise shewing what gond the nunority des in virtue of the sovereign power possessed: bet we are $n$. content that ihese "doctrines" shall be furcel on others, and that Pennsylvania shall give up her "practices" to them; for, with ber alhesion to the "rulcs of the Virginia school," inisery will abound every where, and free laborers be compelled to go supperless to bed, because of the disposition rather to eucourage the importation of Briti-h goods than to protect the mantfacture of like goods at home, though the British people will not consume of all the products of la. bor in Pennsylvania the value of one hundred dollars a year.

The doctrines of one state and the practicts of the other, are well manifested in the following sesolutions, which we offer in contrast.

The third resolution of the series offered by . $11 \mathrm{r}$.

Giles, now governor of lirginia, and passed at

the last session of the legistature, runs as follows:

Resolved, In like manner' [that is, "in behalf of the people and government" of Virginia], that this general assembly does most solemnly protest against the claim or exercise of any power, whatever, on the part of the general government, to protect domestic manufactures, the protection of manuiactures not being amongst the grants of power to that government, specsdied in the constitution of the Uniled States; and also, against the operation of the act of congress, passed May 2zd, 1824, entilled, "an act, to amend the several acts imposing duties on imposts," generally called the tariff law, which vary the distributions of the proceeds of the labor of the coremunity, in such a manner as to transfer property from one portion of the U. States to another; and to take private property from the owner for the benefit of another person, not rendering public service,-as unconstitutional, unwise, unjusi, unequal and oppres. sire.

The following freanble and realution were adofited in the lesistature of l'ensyldamia ine the session of $1823-4$, and intended to have effect in obtaining the passage of the act of May, 1824, which

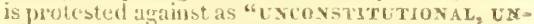
WISE, UNJLST, UXERLA AUd OPRLISSIV E."

"Whereas manufactures have been established in Pennsylvania, by the enterprising patriotic and laudable spirit of individuals and com. panies, at a vast sacrifice of money and time. as they are in a suffering condition, and as congress can alone apjly the remedy; and as their encouragement would freilitate the employmen: of the indigent, and afford a market for the surplus produce of the farmer; and it being the inierest of Pennsylvania that domestic manufac. tures should be cherished and fostered: there. fore,

Be it resolved, by the senate and house of representatives of Pennsylvania, that the senators of the United States, be and they are herebs requested, to adrocate, support and procurs the adoption of any measures having a tender: cy to increase, foster or protect the manufasturing establishments of Pennsyivania.

other like opposing proceedings might be shewn in regard to internal imporemen!: and as tha? subject together with the protection of domestic industry, are, indeed, the onld great matters now a: issue before the American people, it remains to be seen whether Pennsyivania will adopt the "doctrines" of Viruginia or continue stedfast to her own principles and practices. The policy of the two staes are at wriance as much as light is with darkne-s; and it is impossible thet bolh ean th gratified. One must give way to the aldress or power of the other. There is no middle ground; ws "combination" can reconcife the existing disterences of opinion, in matters of foliticit feith an " gractice, as prevailing in them. The policy of Virginia, as it was in the last tyar with Lnglan? would deny, even to our suldiers and sailors a sutheiency of clothing to defend fisem from the inclemency of the seasons when fighting un: battles; Lut that of Penosylvania w!! fi!rri-! ha!r

* af oue of the war loans, Pennsylvania had $\$ 2,340,000$-and Virginia 30 ass 
abundantly, and every wibere cause "the willoness to blussuis as the rose, and rear it foms. male standard of saucy independence!

We shall oniy arif the following extract of a letter latcly received from a correspondent in Vinguia, whu hat had a conversation with the present "head nun" of the learned interpreterg of the constitution in thit state. This distingushed indiridual asserted, that, "if the the wool bill had passed, or any finther restrictions shill be made on foreign goods, that Virrima and al! the sonthern states wnula or will] prohibit. Hem Englani goods, or lay a duty on them equal to atat bitl by the Cimled sictes on the foreinn." We helieve this, for we have personally heard the same thing said, by a Virginian, and laughed heartily at it, three or four years ago; except that the disciple then went further, and swore most lublit, that lirginia weuld forbid the introtuc. Eion of any article mantactured north of the Potomac! 'This is literally the truth. Virginia malre

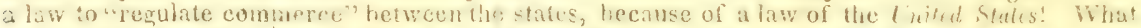
a "construction of the coustitution" wev!d that he! It is tou ridiculous for serious repretiension. It is the frog blowing itself to equal the size of the ox.

"wlead man." We use this appellation in a scrious manner, and with referenee to the char' actor it implies, because of the efiect that would follow the policy supported. We speak with whthorily before us. In Dec. 1\$15, that late excellent whig, Bengamin. Iustin, addressed a letter to THOMAS JEFFERSON, requesting his opinions on the propriety and necessity of encouraging domestie manufactures. The latter, under date of Jan. 9, 1816 , fully and frankly replied to his

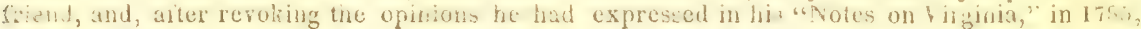
stid-

"We have experienced what we did not then believe, that there exists both prolligacy and power enough to exclude us from the field of interchange with other nations; that to be indepen-

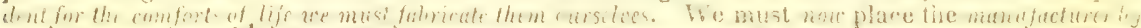

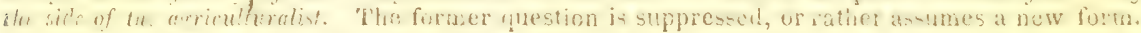
The grand enquiry now is, shall we make on onen comforts or go wilhout them ul the will of a fortion

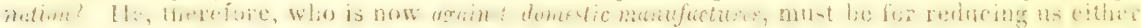
to a dependence on that nation, or be clothed in skins, and to live like wild beasts in dens and caverns, I am proud to say, I AM NOT ONE OF THESE. Experience has taught me that manufacfures are now as necessary to our independence as to our comfort-and if those who quote me as of a dufforent opinion, will keep pace with me in purchasing nothing forcign. where an equivojent of domestic fabric can be obtained, without regarl lo diference of frice, it will not be our fault

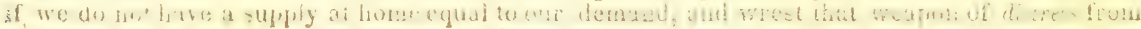
the liand which has so long wantonly wielded it."

E Every word in this extract "tells." It is the voice of him who drafted that "fanfaronade of nonsense," as John Randolph calls the declaration of independence, pleading to the people that independence may be preserved! Rather than be a SAVA GE-"live like a vild becst in dens and carerns," he would purchase home-made goods, "witlout regard to difference of price." What would he then not have done when the fact is manifested to the American people, that r RotectED MANUFACTURES are all at LESS PRICE than the FOREIGN ONES wore before that poteclion was extended: This is the truth. Eren Mr. Cambreleng will not deny it.

$$
\text { Nerites: }
$$

(A.) The reader will please bear in mind that the amount of onn arricultural productions consumed by the people of Great Britaiu and Ireland, is always regarded. In the ycar stated, we

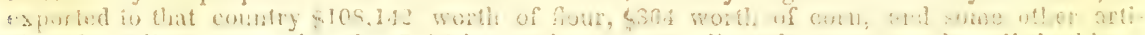
cles of small amounts-but the British people were not allowed to eat even these littie thines, which must liave been bonded for "exportation," if exceeding the quantities required for shin stores. Haxceed, however, to the value of about $\$ 10,000$ dollars was exported and used in il:s United kingdom-which returus to us again in the shape of linens, which we ought to make for oursclucs,

(B) It is estimated that the value of the property which descended the Susquelamah to the fide, in the last year was 5,430,000 ciollars: a wive greater than that of all the Hour exported tu

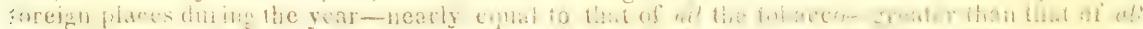

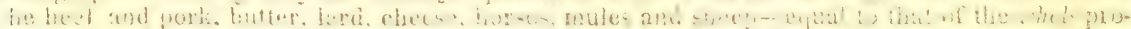
duct of the forest, and three times as large as that of the yroduct of the scu. Who would bave thought this? And yet it is so. 










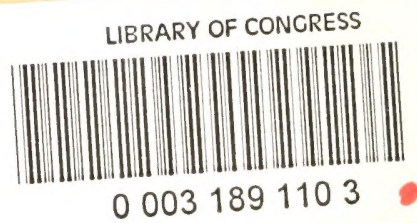

